\title{
KARAKTERISTIK UKURAN BUTIR DAN MINERAL LIAT TANAH PADA KEJADIAN LONGSOR (STUDI KASUS: SUB DAS JENEBERANG)
}

\author{
The Characteristics of Grain-Sizes and Soil Clay Minerals in Landslide Area \\ (Case Study: Jeneberang Sub-watershed) \\ ${ }^{1 *}$ Nur Isra, ${ }^{1}$ Syamsul Arifin Lias, ${ }^{1}$ Asmita Ahmad \\ ${ }^{1}$ Departemen Ilmu Tanah, Fakultas Pertanian, Universitas Hasanuddin, Makassar \\ *Corresponding email: isranurisra@gmail.com
}

\section{ABSTRACT}

Landslide can be triggered by the soil characteristics, especially in grain sized and clay minerals. The stability of Jeneberang sub-watershed area after the collapse of Mt. Bawakaraeng caldera caused a disruption around the sub-watershed areas. This research aims to determine the characteristics of grain-sizes and clay minerals in Jeneberang sub-watershed in a landslide area. This research used a quantitative descriptive method to identify the grain-size using ASTM sieves size 48mesh and clay minerals using FTIR. Soils were taken from landslide point-area and non-landslides area with the same of topography and geology characteristics. The area was dominated with hilly to steep topography and the average annual precipitation of the last eight years was 3484 $\mathrm{mm} /$ year. The result of analysis grain-size for all landslide point-area and the comparison was dominated by $0.5 \mathrm{~mm}$ and categorized as subrounded in landslides area; TL1, TL3, TL5, TL6, TL7, TL8, and TL 10, and no-landslides area; TPB3, and TPB4, while subangular was showed in landslides area; TL2, TL4, TL9, and nolandslides area; TPB1, and TPB2. Minerals analysis showed the dominant clay minerals founding in landslides area; TL1, TL2, TL3, TL10, and no-landslides area; TPB1, TPB2 was kaolinite, and in landslides area; TL6, TL5 was halloysite. Montmorillonite was found in landslides area; TL8, TL4, and chlorite found in landslides area; TL9, TL7, and no-landslides area; TPB3, while nacrite
\end{abstract}

was found in no-landslides area; TPB4. Landslides in study area were triggered by present of kaolinite, halloysite, montmorillonite and chlorite minerals in soils, while grain-sized given not much contribution to landslides events.

Keywords: Jeneberang sub-watershed, landslide, grain-sizes, clay minerals

\section{PENDAHULUAN}

Longsor merupakan proses perpindahan material tanah atau batuan atau kombinasinya yang sering terjadi pada daerah lereng yang bergerak pada arah tegak, mendatar, atau miring dari kedudukan semula sebagai proses untuk mencari keseimbangan baru akibat adanya gangguan atau faktor yang mempengaruhinya (Husain, 2015).

Faktor yang mempengaruhi terjadinya longsor lahan menurut Thornburry (1969), meliputi faktor pasif dan faktor aktif. Longsor dapat dipicu oleh karateristik tanah yang terbentuk pada wilayah tersebut yang dipengaruhi oleh ukuran fraksi tanah, terutama fraksi tanah yang berukuran lebih halus, yaitu fraksi tanah dari mineral liat (Solle and Ahmad, 2016). Stabililitas wilayah sub DAS Jeneberang pasca kejadian runtuhnya kaldera Gunung Bawakaraeng, menyebabkan gangguan berupa longsoran disekitar wilayah sub DAS lainnya. 


\section{METODOLOGI}

Penelitan ini dilaksanakan di wilayah Sub DAS Jeneberang bagian hulu. Analisis FTIR dilakukan di laboratorium Kimia Dasar Fakultas Matematika dan Ilmu Pengetahuan Alam Universitas Hasanuddin. Analisis sifat fisik dan kimia tanah dilakukan di Laboratorium Kimia dan Kesuburan Tanah Departemen Ilmu Tanah Fakultas Pertanian Universitas Hasanuddin.

Alat yang digunakan yaitu: Perangkat keras (hardware) dan perangkat lunak (software) serta alat-alat laboratorium. Perangkat keras berupa seperangkat alat survey, seperangkat komputer, GPS, dan kamera. Perangkat lunak yaitu Arc GIS 10.3. adapun alat-alat yang digunakan dalam analisis mineral tanah, analisis sifat fisik dan kimia tanah (Tabel 2).

Tabel 2. Alat yang digunakan dalam analisis sampel tanah di laboratorium

\begin{tabular}{|l|l|l|}
\hline$N_{0}$ & Jenis Analisis & Peralatan \\
\hline 1 & Mineral liat tanah & FT-IR Spektrofotometer \\
\hline 2 & Sifat fisik tanah & \\
\hdashline & Distribusi ukuran butir & $\begin{array}{l}\text { Saringan ASTM standar, timbangan analitik, dan mikroskop } \\
\text { binokuler }\end{array}$ \\
\hdashline 3 & $\begin{array}{l}\text { Tekstur } \\
\text { Sifinder sedimentasi } 800 \mathrm{ml} \text {, penyaing, ayakan } 50 \text { mikron, } \\
\text { gelas ukur } 500 \mathrm{ml} \text {, timbangan analitik, labu semprot, } \\
\text { temometer, dan hidrometer. }\end{array}$ \\
\hline & C-organik & $\begin{array}{l}\text { Labu ukur } 250 \mathrm{ml} \text {, gelas ukur } 10 \mathrm{ml} \text {, pipet volume } 50 \mathrm{ml} \text {, pipet } \\
\text { tetes. }\end{array}$ \\
\hline
\end{tabular}

Bahan yang digunakan dalam penelitian ini adalah sampel tanah terganggu, Peta Rupa Bumi skala 1:50.000, peta Administrasi Kab. Gowa, Data SRTM 30, data curah hujan wilayah DAS Jeneberang delapan tahun terakhir (2009 sampai 2016), titik longsor yang terjadi pada DAS Jeneberang, bahan kimia untuk analisis sampel tanah (Tabel 3).

\section{Metode dan Tahapan Penelitian}

Metode yang digunakan dalam penelitian ini adalah metode survei dengan melakukan pengamatan di lapangan pada titik longsor yang ditetapkan berdasarkan data sekunder kejadian longsor tahun 2009 dan didukung oleh data kemiringan lereng, jenis tanah, kondisi geologi dan dari hasil analisis laboratorium, sehingga disusunlah tahapantahapan kerja yakni studi literatur, pembuatan peta kerja, survei lapangan, dan analisis laboratorium.

Tabel 3. Bahan kimia/pereaksi yang digunakan dalam analisis sampel tanah

\begin{tabular}{|c|c|c|c|}
\hline $\mathrm{N}_{0}$ & Jenis Analisis & Bahan & Metode \\
\hline 1 & $\begin{array}{l}\text { Mineral liat } \\
\text { tanah }\end{array}$ & Sampel tanah fraksiliat & $\begin{array}{l}\text { FTIR (Fourier } \\
\text { Trasform Infra Red) }\end{array}$ \\
\hline \multirow[t]{3}{*}{2} & Sifat fisik tanah & & \\
\hline & $\begin{array}{l}\text { Distribusi } \\
\text { ukuran butir }\end{array}$ & Sampel tanah terganggu $100 \mathrm{~g}$ & Saringan ASTM \\
\hline & Tekstur & $\begin{array}{l}\text { Sampel tanah terganggu } 20 \mathrm{~g} \text {, lantan } \\
\mathrm{Na}_{4} \mathrm{P}_{2} \mathrm{O} \text {. }\end{array}$ & Hydrometer \\
\hline \multirow[t]{2}{*}{3} & $\begin{array}{l}\text { Sifat kimia } \\
\text { tanah }\end{array}$ & & \\
\hline & C-organik & $\begin{array}{l}\text { Sampel tanah terganggu } 1 \mathrm{~g}, \mathrm{~K}_{2} \mathrm{Cr}_{2} \mathrm{O}_{7} 1 \mathrm{~N} 5 \\
\mathrm{ml}, \mathrm{H}_{2} \mathrm{SO}_{4} 5 \mathrm{ml} \text {, Amonium } \mathrm{Fe} \text { (II) Sulfat } \\
0,25 \mathrm{~N} \text {, indikator diphenylamine } 5 \text { sampai } \\
10 \text { tetes }\end{array}$ & Walkey and Black \\
\hline
\end{tabular}

\section{Studi Literatur}

Studi literatur berfungsi untuk mengumpulkan informasi serta data-data yang dibutuhkan. Informasi berkaitan dengan sumber pustaka yang diperlukan dan data berupa data curah hujan delapan tahun terakhir, peta curah hujan, peta geologi, peta jenis tanah, dan peta topografi. Peta-peta tersebut dapat digunakan untuk memperoleh informasi tentang kondisi lokasi.

\section{Survei Lapangan}

Tujuan survei lapangan adalah untuk mengamati, memperhatikan dan mencatat hal-hal yang penting di lokasi yang berpotensi memengaruhi kestabilan lereng. Dalam survei lapangan juga dilakukan pengambilan sampel tanah untuk selanjutnya di analisis di laboratorium pada titik yang telah ditentukan. Pada lokasi penelitian difokuskan pada bagian hulu sub DAS Jeneberang. Titik sampel terdiri atas dua kelompok, yaitu:

1. Titik longsor (TL) ditetapkan berdasakan kejadian longsor yang terjadi berjumlah sepuluh titik.

2. Titik pembanding (TPB) ditetapkan berdasarkan kelas lereng yang sama 
dengan kejadian longsor yang berjumlah empat titik.

\section{Analisis Laboratorium}

Analisis sampel tanah dilakukan dua tahapan yaitu analisis mineral liat dengan metode FTIR (Fourier Trasform Infra Red) untuk mengetahui komposisi mineral liat tanah, dan sebelum dilakukan analisis beberapa contoh tanah dikering udarakan. Selanjutnya dilakukan analisis sifat fisik dan kimia sampel tanah di laboratorium berupa:

1. Klasifikasi butiran yakni sampel di ayak untuk menentukan distribusi ukuran butir dengan analisis saringan (siever analysis), pada metode ini dilakukan dengan menggunakan alat ayakan ASTM 48, dan sampel dipreparasi, yang telah dikeringkan ditimbang seberat 100 gram ditaruh pada ayakan paling atas, kemudian saringan digetarkan dan butiran akan tertinggal pada masingmasing saringan sesuai dengan ukuran dan prosentasinya lalu ditimbang. Ayakan yang digunakan dengan susunan saringan no.4,8,10,18,40,60,80,100,200, dengan lubang ayakan, dalam mm yakni $25.2,19,9.5,4.8,2.00,1.00,0.50,0,335$, $0.250,0.180,0.125,0.063$, dan $>0.063$.

2. Tekstur tanah yakni perbandingan relatif antara fraksi debu, liat dan pasir. Tekstur tanah dapat diketahui dengan cara melihat persentase masing-masing partikel yang kemudian dilakukan penetapan kelas tekstur menurut USDA.

3. C-organik yakni C-organik akan mempengaruhi kandungan bahan organik tanah, semakin tinggikandungan $\mathrm{C}$ organik maka semakin meningkat kandungan bahan organik.

\section{KONDISI UMUM WILAYAH}

\section{Lokasi Penelitian}

Lokasi penelitian berada di Sub DAS Jeneberang bagian Hulu, Kabupaten Gowa,
Sulawesi Selatan. Sungai Jeneberang merupakan sungai besar yang terletak pada bagian barat dalam wilayah administrasi Kotamadya Makassar, ibukota dari Provinsi Sulawesi Selatan. Sungai ini berasal dan mengalir dari bagian timur Gunung Bawakaraeng (2,833 mdpl) dan Gunung Lampobatang $(2,876)$ yang kemudian menuju hilirnya di Selat Makassar. Secara geografis Daerah Aliran Sungai Jeneberang terletak pada $119^{\circ} 23^{\prime} 50^{\prime \prime} \mathrm{BT}-119^{\circ} 56^{\prime} 10^{\prime \prime}$ BT dan $05^{\circ} 10^{\prime} 00^{\prime \prime} \mathrm{LS}-05^{\circ} 26^{\prime} 00^{\prime \prime} \mathrm{LS}$ dengan panjang sungai utamanya 78.75 kilometer.

\section{Keadaan Curah Hujan}

Terdapat dua stasiun yang dirata-ratakan dalam rentan waktu delapan tahun (2009 sampai 2016) curah hujan yang mencakup Sub DAS Jeneberang bagian Hulu, yaitu Data Curah Hujan BPP Tinggi Moncong yang terletak pada koordinat $119^{\circ} 51^{\prime} 13.2^{\prime}$ " BT dan $05^{\circ} 15^{\prime} 10.8^{\prime \prime}$ LS, dan Data Curah Hujan BBI HORTI, Kec. Parangloe yang terletak pada koordinat $119^{\circ} 34^{\prime} 03.8^{\prime \prime} \mathrm{BT}$ dan $05^{\circ} 17^{\prime}$ 08.4" LS. Curah hujan tertinggi berada pada bulan Januari dan Februari di masing-masing stasiun.

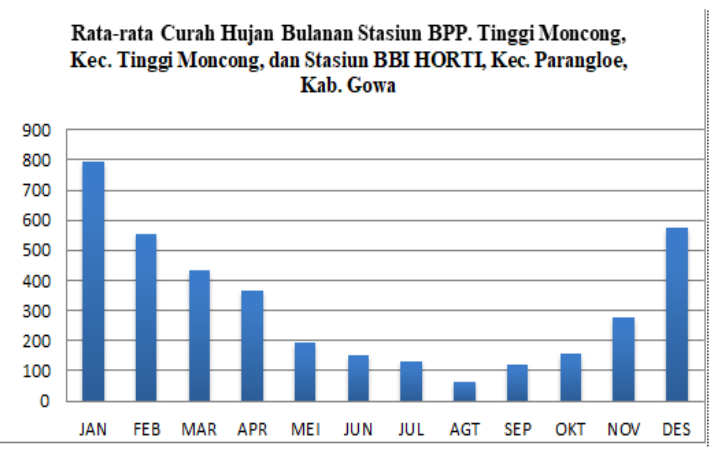

Gambar 1. Grafik rata-rata curah hujan bulanan ( $\mathrm{mm} /$ bulan) tahun 2009-2016.

\section{Topografi}

Pada umumnya, tanah longsor dapat terjadi pada wilayah yang berlereng. Semakin curam suatu kelerengan maka semakin 
tinggi potensi longsornya. Berdasarkan data dari SRTM 90 (Tabel 5).

Tabel 5. Data topografi

\begin{tabular}{|c|c|c}
\hline Kelas lereng (\%) & Kategori & Luas (ha) \\
\hline 0 sampai 3 & Datar & 0 \\
3 sampai 8 & Berombak & 698 \\
8 sampai 15 & Bergelombang & 1.457 \\
15 sampai 25 & Agak curam & 3.862 \\
\hline 25 sampai 45 & Curam & 14.071 \\
\hline Lebih dari 45 & Sangat curam & 5.859 \\
\hline & Total & 25.947 \\
\hline
\end{tabular}

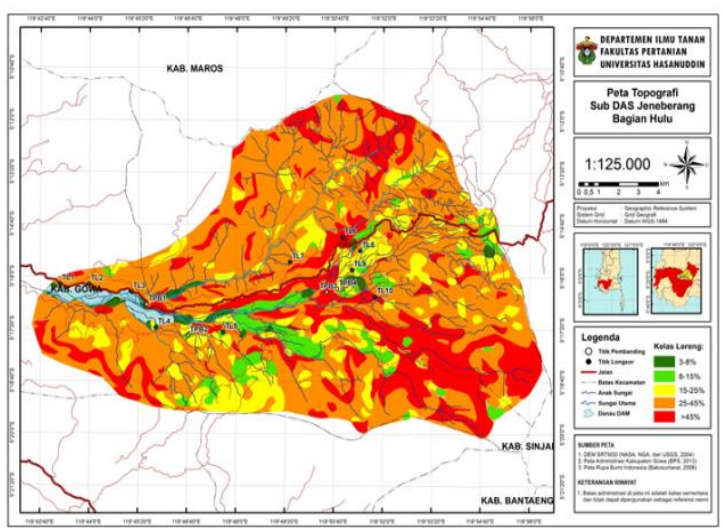

Gambar 2. Peta topografi

\section{Geologi}

Berdasarkan data landsystem RePProt (Regional Physical Planning Program For Transmigration), diketahui jenis batuan induk yang terdapat pada daerah penelitian (Tabel 6).

Tabel 6. Kondisi Geologi

\begin{tabular}{c|l|l|}
\hline Nomor & Batuan Induk & Luas (ha) \\
\hline 1 & Tufa; batulempung; batupasir & $10.252,52$ \\
\hline 2 & Andesit; Basalt & 4954,57 \\
\hline 3 & Aluvium sungai & 2874,55 \\
4 & Basalt; andesit & 3296,16 \\
\hline 5 & Andesit; Basalt; tufa halus & 4569,27 \\
\hline & Total & $\mathbf{2 5 . 9 4 7}$ \\
\hline
\end{tabular}

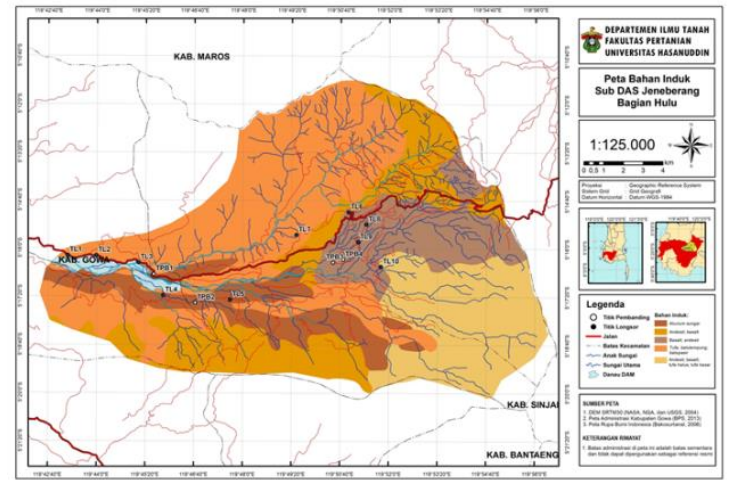

Gambar 3. Peta geologi

\section{Jenis Tanah}

Berdasarkan data yang diperoleh dari RePProt (Regional Physical Planning Program For Transmigration), diketahui jenis tanah yang terdapat pada daerah penelitian adalah ordo inceptisol dan ultisol, dan pada great group (Tabel 7).

\section{Tabel 7. Jenis Tanah}

\begin{tabular}{|c|l|l|}
\hline Nomor & Jenis Tanah & Luas (ha) \\
\hline 1 & Dystropepts; Haplorthox; Tropudults & 3433,36 \\
\hline 2 & Dystropepts; Humitropepts; Tropohumults & 2531,75 \\
\hline 3 & Tropaquepts; Tropofluvents & 1433,33 \\
\hline 4 & Dystropepts; Tropudalfs; Tropudults & 3296,16 \\
\hline 5 & Dystropepts; Tropohumults & 2725,69 \\
\hline 6 & Dystropepts; Tropudults & 1441,22 \\
\hline 7 & Dystropepts; Haplorthox; Tropudults & 1404,86 \\
\hline 8 & Paleudults; Haplorthox; Dystropepts & 2688,6 \\
\hline 9 & Dystropepts; Tropudults; Troperthents & 2422,83 \\
\hline 10 & Humitropepts; Dystrandepts; Hydrandepts & 4569,27 \\
\hline & Total & $\mathbf{2 5 . 9 4 7}$ \\
\hline
\end{tabular}

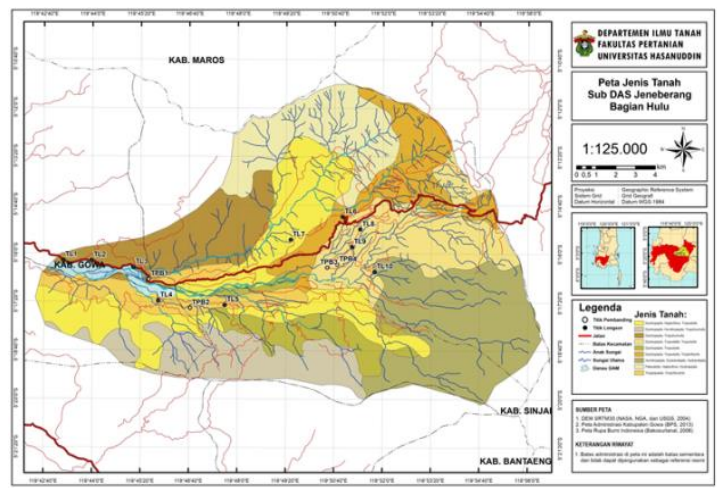

Gambar 4. Peta jenis tanah 


\section{HASIL DAN PEMBAHASAN}

\section{Ukuran dan bentuk Butir Tanah}

Berdasarkan hasil pengamatan, bentuk butiran diklasifikasikan berdasarkan New Zealand Geotechnical society (NZGS) tahun 2005, ditunjukkan pada Tabel 8.

Berdasarkan Tabel 8, bentuk butiran subrounded terdapat pada tujuh titik longosr dan dua pada titik pembanding, dua titik longsor dan dua titik pembanding bentuk butirnya berupa subangular. Yanti (2015) menyatakan bahwa, bentuk butiran berupa subrounded yang bentuknya membulat tidak sempurna, mengurangi gaya gesek antar butiran sedangkan bentuk butiran subangular memiliki sisi yang lancip sehingga membuat pori kecil yang dapat terisi oleh butiran yang ukurannya lebih kecil atau dapat terisi oleh air.

Tabel 8. Gradasi dan bentuk butiran

\begin{tabular}{|c|c|c|c|}
\hline Nomor & Kode & Bentuk & Gradasi \\
\hline 1 & TL1 & Subrounded & Seragam \\
\hline 2 & TL2 & Subangular & Seragam \\
\hline 3 & TL3 & Subrounded & Seragam \\
\hline 4 & TL4 & Subangular & Seragam \\
\hline 5 & TL5 & Subrounded & Seragam \\
\hline 6 & IL6 & Subrounded & Seragam \\
\hline 7 & TL7 & Subrounded & Seragam \\
\hline 8 & TL8 & Subrounded & Seragam \\
\hline 9 & TL9 & Subangular & Seragam \\
\hline 10 & TL10 & Subrounded & Seragam \\
\hline 11 & TPB1 & Subangular & Seragam \\
\hline 12 & TPB2 & Subangular & Seragam \\
\hline 13 & TPB3 & Subrounded & Seragam \\
\hline 14 & TPB4 & Subrounded & Seragam \\
\hline
\end{tabular}

Gradasi tanah yang ditunjukkan pada data yaitu gradasi seragam (uniform grade) pada semua titik longsor dan titik pembanding. Jika gradasinya seragam maka dapat terbentuk pori mikro diantara butiran yang kemudian diisi oleh air dan membuat tanah mudah jenuh dan beban tanah akan meningkat sehingga dapat memicu terjadinya longsor. Hal ini sesuai dengan Hadiatmo (2006) dalam Rahayu (2015) sebab terjadi dominasi ukuran butir pasir halus dan atau terjadi sebaran butir yang tidak merata pada tanah. Pasir halus yang mendominasi tanah akan membentuk pori mikro dalam jumlah banyak maka kemampuan tanah dalam meloloskan air (permeabilitas) akan terhambat.

\section{Tekstur Tanah}

Tekstur menunjukan sifat halus atau kasar butiran-butiran tanah lebih khas lagi tekstur ditentukan oleh perimbangan kandungan antara pasir (sand) liat (clay) dan debu (slit) yang terdapat dalam tanah. tekstur digunakan untuk menunjukkan ukuran partikel-partikel tanah, terutama pada perbandingan relatif berbagai golongan tanah. Tanah bertekstur pasir dan debu sangat rentan terhadap longsor dibandingkan dengan tekstur liat yang memiliki daya menahan air lebih baik. Hasil analisis tekstur (Tabel 9).

Tabel 9. Tekstur tanah

\begin{tabular}{|c|c|c|}
\hline Nomor & Kode & Tekstur \\
\hline 1 & TL1 & Liat \\
\hline 2 & TL2 & lempung liat berpasir \\
\hline 3 & TL3 & lempung berdebu \\
\hline 4 & TL4 & Liat \\
\hline 5 & TL5 & lempung berdebu \\
\hline 6 & TL6 & lempung berpasir \\
\hline 7 & TL7 & Lempung \\
\hline 8 & TL8 & Lempung \\
\hline 9 & TL9 & Lempung \\
\hline 10 & TL10 & lempung berpasir \\
\hline 11 & TPB1 & lempung berpasir \\
\hline 12 & TPB2 & Lempung \\
\hline 13 & TPB3 & Lempung \\
\hline 14 & TPB4 \\
\hline & & \\
\hline
\end{tabular}

Tabel di atas menunjukkan bahwa terdapat lima kelas tekstur tanah berdasarkan USDA yaitu liat yang termasuk kategori halus pada tiga titik, lempung yang termasuk kategori sedang pada lima titik, lempung liat berpasir yang termasuk kategori agak halus pada satu titik, lempung berdebu pada dua titik yang termasuk kategori sedang, dan lempung berpasir yang termasuk kategori kasar pada tiga titik. Terdapat keragaman kelas tekstur pada titik longsor yaitu halus sampai sedang. Semakin liat atau halus suatu tekstur tanah maka semakin banyak ruang pori mikro yang terbentuk yang terisi oleh air dan udara. 
Apabila terjadi akumulasi air pada tanah yang berada pada titik longsor yang tergolong bergelombang hingga sangat curam akan menambah beban lereng dan dapat memicu terjadinya longsor hal ini sesuai dengan pendapat Hardiyatmo (2006) bahwa, kestabilan lereng yang tanahnya berliat sangat dipengaruhi oleh banyaknya air yang meresap ke dalam tanah, selain itu akibat infiltrasi air hujan, berat tanah bertambah.

\section{Bahan Organik Tanah}

Bahan organik berfungsi untuk mengikat partikel-partikel tanah menjadi lebih remah untuk meningkatkan stabilitas struktur tanah meningkatkan kemampuan tanah dalam menyimpan air. Kandungan bahan organik dapat diketahui dari kandungan $\mathrm{C}$-organik. Analisis di laboratorium diperoleh hasil pada (Tabel 10).

Tabel 10. C-organik tanah

\begin{tabular}{|c|c|c|c|}
\hline \multirow{2}{*}{ Nomor } & \multirow{2}{*}{ Kode } & \multicolumn{2}{|c}{ C-Organik } \\
\cline { 3 - 4 } & & $(\%)$ & Kriteria \\
\hline 1 & TL1 & 2,00 & Sedang \\
\hline 2 & TL2 & 2,23 & Sedang \\
\hline 3 & TL3 & 0,68 & Sangat rendah \\
\hline 4 & TL4 & 2,65 & Sedang \\
\hline 5 & TL5 & 1,16 & Rendah \\
\hline 6 & TL6 & 2,71 & Sedang \\
\hline 7 & TL7 & 1,24 & Rendah \\
\hline 8 & TL8 & 2,67 & Sedang \\
\hline 9 & TL9 & 2,84 & Sedang \\
\hline 10 & TL10 & 0,51 & Sangat rendah \\
\hline 11 & TPB1 & 1,68 & Rendah \\
\hline 12 & TPB2 & 2,67 & Sedang \\
\hline 13 & TPB3 & 2,83 & Sedang \\
\hline 14 & TPB4 & 2,59 & Sedang \\
\hline
\end{tabular}

Data menunjukkan kandungan COrganik tanah pada lokasi penelitian berkisar dari sangat rendah hinnga sedang (0,51 sampai 2,84) Hal ini dipengaruhi oleh tingginya intensitas curah hujan pada lokasi penelitan yang mentebabkan terjadinya pencucian hara. Dengan demikian, Corganik sebagai pemantap agregat tidak berfungsi secara optimal. Jika kadar Corganik rendah akan menyebabkan agregat tanah tidak stabil (Ahmad et al., 2017), hal ini juga sesui dengan pernyataan Madjid
(2010) bahwa kandungan bahan organik yang rendah menyebabkan partikel tanah mudah pecah oleh curah hujan dan terbawa oleh aliran permukaan, yang pada kondisi ekstrim mengakibatkan terjadinya longsor lahan.

\section{Hubungan Antar Faktor Penyebab Longsor dengan Potensi Kejadian Longsor}

\section{Titik Longsor (TL1, TL2, TL3, TL7 dan TP1)}

Titik longsor 1 (119 $43^{\prime} 13,813^{\prime \prime} B T$ dan $5^{\circ} 17$ '29,52” LS), titik longsor 2 (11943'58,37’' BT dan 5¹6'11,934” LS ), titik longsor $3\left(119^{\circ} 45^{\prime} 7,349^{\prime}\right.$ " BT dan 5 16'21,432" LS) berada di kecamatan Parangloe, dan titik longsor 7 (11949'45,045' BT dan 5'16'03,677' LS) berada di kecamatan tinggi moncong. Karakteristik medan berada pada daerah curam. Bahan induk dari tempat kejadian longsor adalah tufa, batulempung, dan batupasir. Longsor terjadi pada bulan Februari dengan rata-rata curah hujan 4602 $\mathrm{mm} / \mathrm{bulan}$.

Kenampakan bekas longsor pada (Gambar 5), dan karakteristik sifat tanah pada (Tabel 10), serta kenampakan bentuk butiran pada (Gambar 6).

Berdasarkan hasil analisis menggunakan saringan SRTM pada TL1, TL2, TL3, dan TL7 distribusi ukuran butiran menunjukkan bahwa tanah bergradasi seragam yang didominasi oleh ukuran 0,5 mm dengan persentase pada TL1 (31\%), TL2 $(38,4 \%)$, TL3 $(38,6 \%)$ dan TL7 $(54,6 \%)$ serta pada saringan dengan ukuran $2 \mathrm{~mm}, 1$ $\mathrm{mm}, 0,063$, dan $>0,063 \mathrm{~mm}$ persentase yang lolos dibawah 5 persen. Hal ini menunjukkan bahwa sebaran butiran tidak merata. Hardiyatmo (2006) berpendapat bahwa jika gradasi semakin baik maka semakin besar gaya menahan pada lereng. 


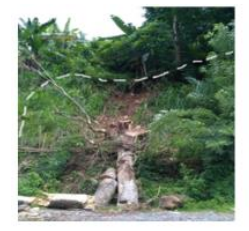

(a)

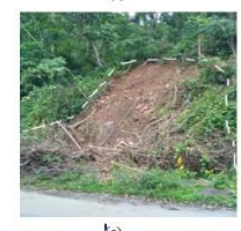

(c)

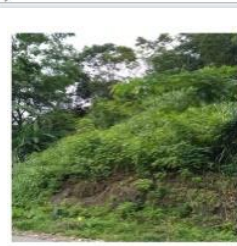

Gambar 5. Bekas longsor pada (a) TL1 (b) TL2 (c) TL3 (d) TL7, dan (d) pembanding kejadian longsor (TPB1)

Tabel 11. Karakteristik sifat tanah TL1, TL2, TL3, TL7, dan TPB1
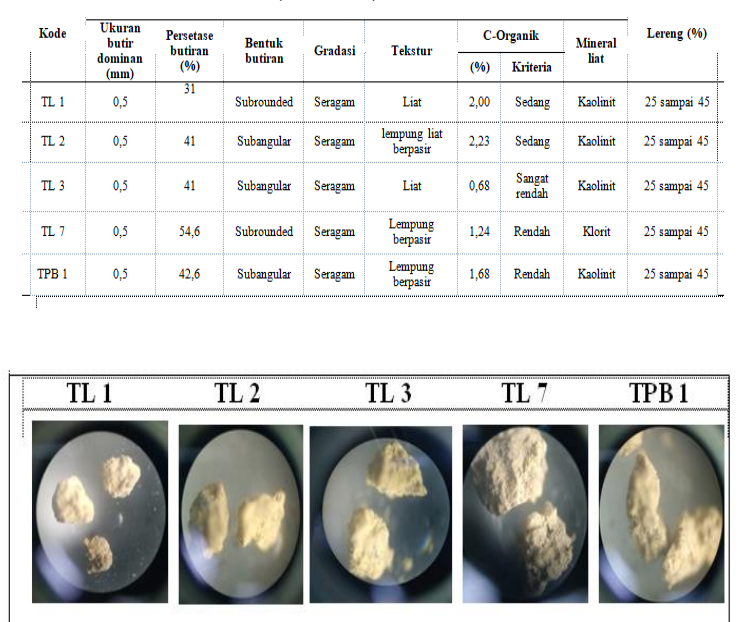

Gambar 6. Bentuk butiran ukuran pembesaran $10 \mathrm{x}$

Berdasarkan analisis hydrometer tekstur tanah pada TL1 adalah liat, tekstur tanah pada TL2 adalah lempung liat berpasir, dan tekstur tanah pada TL3 adalah liat. Menurut USDA dalam Arsyad (2006), tekstur liat termasuk kelompok tekstur halus, lempung liat berpasir termasuk kelompok tekstur agak halus, dan tekstur lempung berpasir termasuk kelompok tekstur kasar.
Semakin halus tekstur tanah semakin banyak menyimpan air dan permeabilitas lambat. Ukuran butiran yang tidak merata dan banyaknya intensitas air yang tertampung dalam tanah serta berada pada kelerengan yang curam akan mudah mengalami longsor.

Berdasarkan hasil analisis FTIR kandungan mineral liat dominan pada TL1, TL2, dan TL3 adalah kaolinit. Mineral kaolinit merupakan mineral tipe 1:1 berwujud seperti lempengan tipis-tipis. tanah yang mengandung mineral liat kaolinit memiliki kapasitas mengembang dan mengerut yang rendah. Menurut Husain (2015) kaolinit memiliki kapasitas mengembang rendah, sehingga tidak dapat mengabsorpsi air dan kapasitas tukar kation rendah. Jika kemampuan absorpsi air rendah maka permeabilitas lambat. Jika permeabilitas lambat maka akan terjadi akumulasi air yang dapat memicu terjadinya longsor.

Kandungan mineral liat TL7 adalah klorit dengan intensitas 12,337. Klorit termasuk mineral tipe 2:2. Mineral klorit adalah mineral yang tidak dapat mengikat air. Menurut Hanudin (2004) mineral klorit tidak mengembang, ruang antar lapisan terdapat mineral brusit, mengandung $\mathrm{Mg}(\mathrm{OH})_{2}$ pada lapisan oktahedral.

TPB1 merupakan pembanding dari kejadian longsor TL1, TL2, TL3, dan TL7. TPB 1 (119 $45^{\prime} 32,028^{\prime}$ 'BT dan $5^{\circ} 15^{\prime} 44,461$ " LS) berada di kecamatan Parangloe. Berada pada karakteristik medan dan bahan induk yang sama dengan titik kejadian longsor tetapi pada titik ini belum mengalami longsoran. Bentuk butiran pada titik ini yaitu subrounded dan subangular, tekstur tanah dari titik ini yaitu lempung berpasir yang termasuk kategori tekstur kasar. Tekstur yang kasar akan membentuk pori makro yang menyebabkan porositas cepat sehingga tidak terjadi akumulasi air. Menurut Hanafiah (2010) mengemukakan bahwa tanah yang didominasi pasir akan 
banyak mempunyai pori-pori makro atau disebut porous.

Mineral liat dominan pada titik ini adalah mineral kaolinit. Mineral kaolinit termasuk mineral tipe 1:1. Tanah dengan kandungan mineral 1:1 berdainase baik karena mineral ini tidak menjerap air sebab tidak adanya ruang antar misel. Menurut Arsyad (1975) bahwa mineral liat 1:1 terbentuk di daerah beriklim basah dan berdrainase baik dengan lingkungan masam.

\section{Titik Longsor (TL 4, dan TL 5), dan Titik Pembanding (TPB 2)}

Titik longsor 4 (119 $45^{\prime} 45,113^{\prime \prime}$ 'BT dan $5^{\circ} 17^{\prime} 16,482$ ' LS) berada di kecamatan Manuju, titik longsor 5 (11947'40,201" BT dan $5^{\circ} 17^{\prime} 27,636^{\prime \prime}$ LS) berada di kecamatan Parigi, dan titik pembanding 2 (11946'42,078”' BT dan 5¹7'28,032” LS). Karakteristik medan berada pada daerah bergelombang. Bahan induk dari tempat kejadian longsor adalah aluvium sungai. Longsor terjadi pada bulan Februari dengan rata-rata curah hujan $4602 \mathrm{~mm} / \mathrm{bulan}$. Kenampakan bekas longsor pada (Gambar 7), karakteristik sifat tanah pada (Tabel 11), serta kenampakan bentuk butiran pada (Gambar 8)
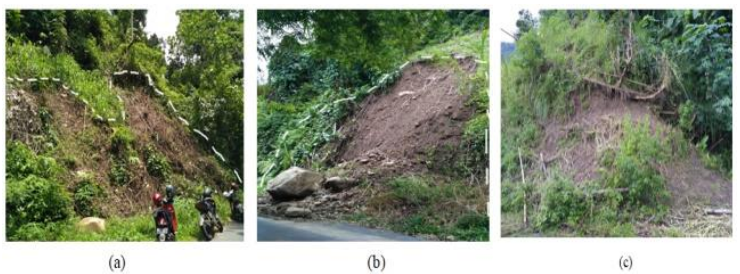

Gambar 7. Bekas longsor pada (a) TL4 (b) TL5, dan (c) pembanding kejadian longsor (TPB2)

Tabel 12. Karakteristik sifat tanah TL4, TL5 dan TPB2

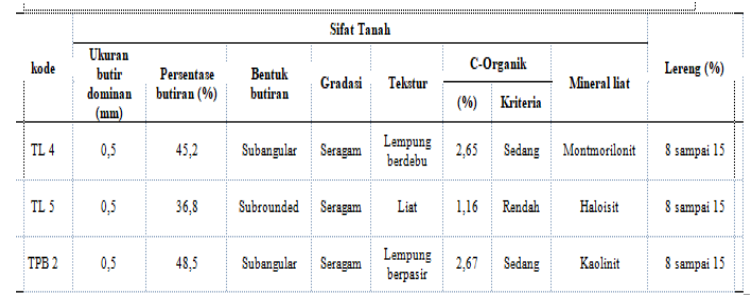

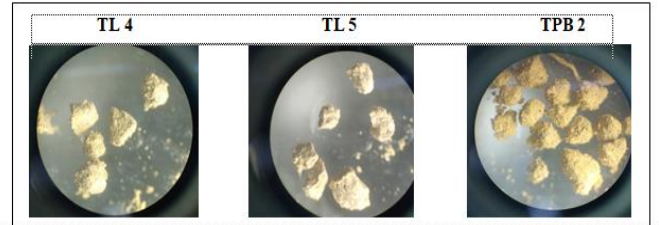

Gambar 8. Bentuk butiran ukuran pembesaran 10x

Berdasarkan analisis saringan ASTM didapatkan bahwa garasi butir pada tiga titik ini adalah seragam. Gradasi yang seragam akan membentuk pori mikro diantara butiran. Hal ini sesuai dengan pendapat Hadiatmo (2004) yang mengemukakan bahwa pasir halus yang mendominasi tanah akan membentuk pori mikro dalam jumlah banyak maka kemampuan tanah dalam meloloskan air akan terhambat dan mengakibatkan terjadinya akumulasi air sehinnga dapat memicu longsor lahan. Dari hasil analisis tekstur tanah didapatkan hasil bahwa TL4 memiliki tekstur yang tergolong sedang, TL5 tergolong tekstur halus, dan TPB2 tergolong tekstur kasar. Menurut Wibowo (2014) semakin halus suatu tekstur tanah semakin banyak ruang pori yang terbentuk diantara partikel yang akan terisi air dan udara.

Hasil analisis FTIR menunjukkan mineral dominan yang terdapat pada TL4 adalah montmorilonit yang tergolong tipe mineral 2:1 yang mampu mengembang apabila dalam kondisi basah dan menyusut dalam kondisi kering. Mineral dominan pada TL5 adalah haloisit. Mineral ini tergolong tipe 1:1 yang kapasitas mengembangnya rendah, hal ini sesuai dengan pendapat Hanudin (2004) bahwa unit-unit kristal diikat bersama secara kuat oleh ikatan hidrogen sehingga tidak dapat memuai (mengembang mengerut) dan sifat plastisitas serta kohesinya rendah. Dari hasil analisis FTIR mineral dominan pada titik TPB4 adalah kaolinit.

TPB4 sebagai pembanding dari titik kejadian longsor TL4 dan TL5. TPB4 mulai menampakkan gejala longsor (Gambar 4c) yaitu terjadinya pengikisan tetapi belum pada tahapan bahaya seperti pada TL4 dan TL5 (Gambar 4a dan 4b) yang material 
longsorannya berupa batuan dan material tanah. TPB4 belum mengalami longsor dikarenakan teksturnya tergolong kasar dan mineral dominan pada titik ini adalah kaolinit yang memiliki daya serap terhadap air rendah sehingga tidak terjadi akumulasi air dalam tanah, hal ini sesuai pendapat Hardiyatmo (2006) bahwa, kestabilan lereng yang tekstur tanahnya halus sangat dipengaruhi oleh banyaknya air yang meresap ke dalam tanah yang dapat menambah berat tanah.

\section{Titik Logsor (TL6, dan TL10), dan Titik Pembanding (TPB3)}

Titik longsor 6 (119 50'49,36"BT dan $5^{\circ} 15 ' 2,785^{\prime}$ " LS) berada di kecamatan Tinggimoncong, titik longsor 10 (11951'44,581' BT dan 5'16’32,099” LS) berada di kecamatan Tinggimoncong, dan titik pembanding $3\left(119^{\circ} 50^{\prime} 31,604\right.$ ' BT dan 5'16’31,832" LS). Karakteristik medan berada pada daerah sangat curam. Bahan induk adalah basalt-andesit. Longsor terjadi pada bulan Februari dengan rata-rata curah hujan $4602 \mathrm{~mm} /$ bulan.

Kenampakan bekas longsor pada (Gambar 9), karakteristik sifat tanah pada (Tabel 12), serta kenampakan bentuk butiran pada (Gambar 10)

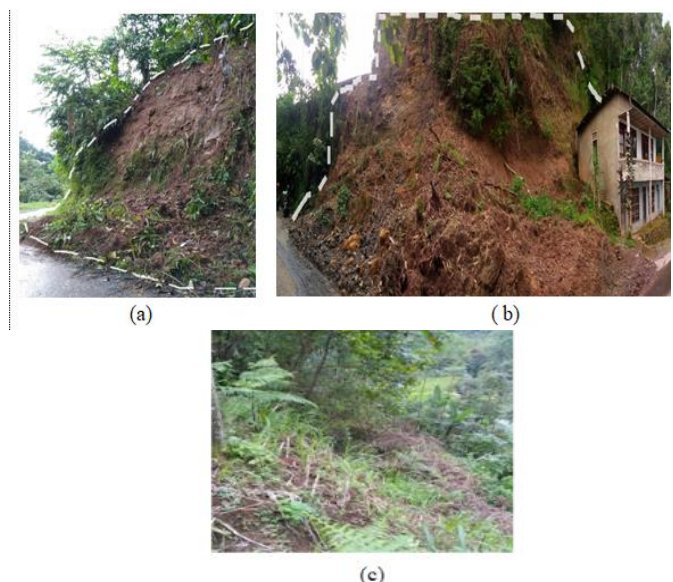

Gambar 9. Bekas longsor pada (a) TL6 (b) TL10, dan (c) pembanding kejadian longsor (TPB3)
Tabel 13. Karakteristik sifat tanah TL6, TL10, dan TPB3.
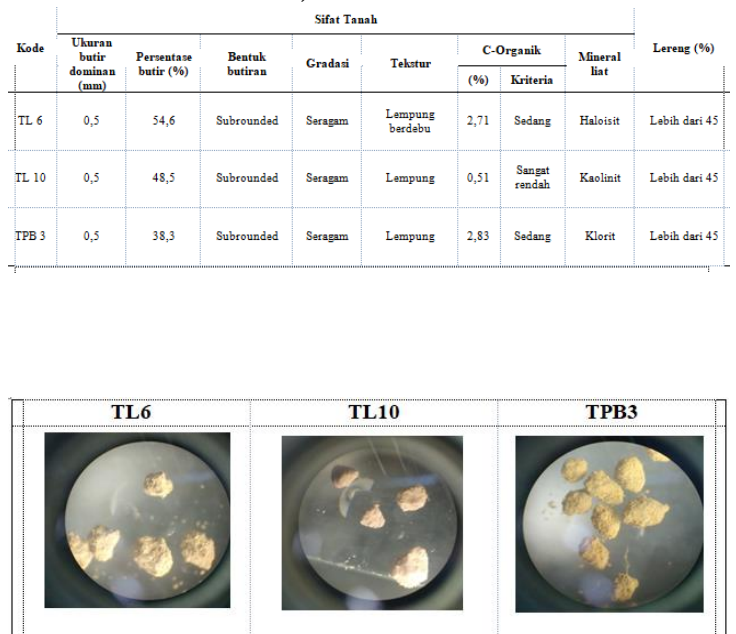

Gambar 10. Bentuk butiran ukuran pembesaran 10x.

Dari hasil analisis ukuran butir dan bentuk butiran didapatkan bahwa gradasi untuk tiga titik ini adalah seragam pada ukuran butir dominan yaitu $0,5 \mathrm{~mm}$ dan bentuk butiran subrounded. Butiran yang seragam dan bentuk butiran yang seragam akan membentuk pori mikro diantara butiran. Tekstur lempung berdebu dan lempung termasuk dalam kategori tekstur sedang.

Hasil analisis mineral liat menunjukkan mineral liat dominan pada TL6 adalah haloisit yang sama pada TL5, mineral liat dominan pada TL10 adalah kaolinit yang sama dengan TL3 dan TPB2. Mineral liat dominan pada TPB3 adalah klorit yang sama pada TP7.

Pada TPB3 belum mengalami longsor lahan seperti pada TL6 dan TL10. Karakteristik lahan yang sangat curam sangat memicu terjadinya longsor. Hal ini sesuai pendapat Massinai et al (2010) bahwa kemiringan lereng yang terjal merupakan faktor lain terjadinya gerakan tanah. Yang membedakan pada tiga titik ini adalah pada TL6 dan TL10 dari segi kandungan mineral liatnya. TL6 mengandung mineral liat haloisit dan TL10 mengandung mineral liat kaolinit yang merupakan tipe mineral liat 1:1, sedangkan mineral liat pada TPB3 mengandung mineral liat klorit yang merupakan tipe mineral liat 2:2. 


\section{Titik Longsor (TL8, dan TL9), dan Titik Pembanding (TPB4)}

Titik longsor 8 (119 $51^{\prime} 426,365^{\prime \prime}$ BT dan $5^{\circ} 15^{\prime} 8,016$ " LS) berada di kecamatan Tinggimoncong, titik longsor 9 (11951'9,26” BT dan 5 $5^{\circ} 15^{\prime} 50,533^{\prime \prime}$ LS ) berada di kecamatan Tinggimoncong, dan titik pembanding 4 (119 $51^{\circ} 1,246^{\prime \prime}$ BT dan 5'16'17,542" LS). Karakteristik medan berada pada daerah agak curam. Bahan induk adalah basalt-andesit. Longsor terjadi pada bulan Februari dengan rata-rata curah hujan $4602 \mathrm{~mm} /$ bulan.

Kenampakan bekas longsor (Gambar 8), karakteristik sifat tanah (Tabel 13), serta kenampakan bentuk butiran (Gambar 9). Hasil analisis ukuran butir didapatkan bahwa ukuran butir pada ketiga titik adalah seragam yang dominan pada ukuran $0,5 \mathrm{~mm}$. Hasil analisis tekstur adalah lempung dimana tekstur lempung tergolong dalam tekstur sedang.

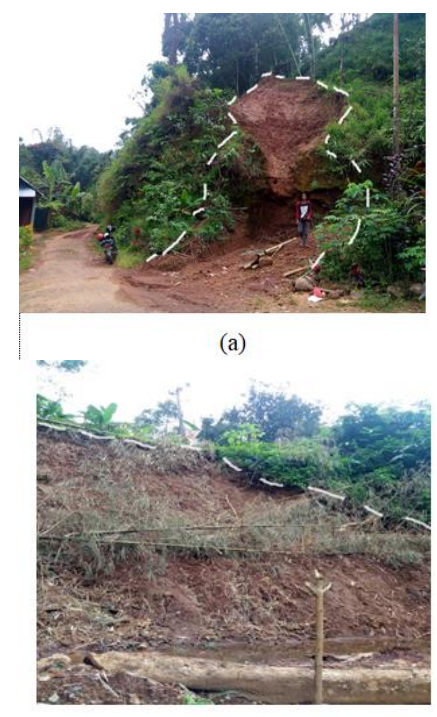

(b)

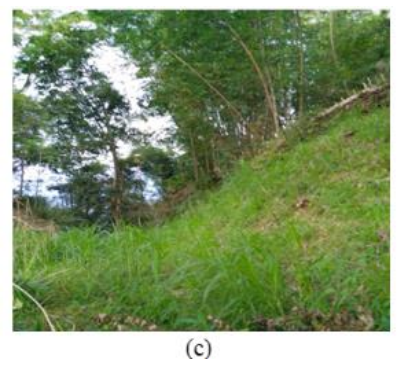

Gambar 8. Bekas longsor pada (a) TL8 (b) TL9, dan (c) pembanding kejadian longsor (TPB4)
Tabel 14. Karakteristik sifat tanah TL8, TL9, dan TPB4
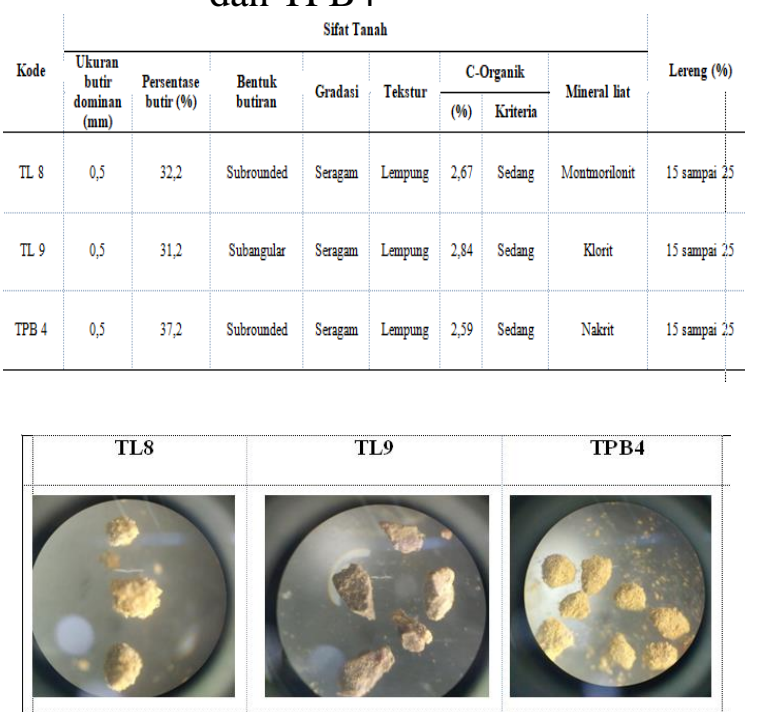

Gambar 9. Bentuk butiran ukuran pembesaran $10 \mathrm{x}$

Mineral liat yang ditemukan pada TPB4 adalah nakrit yang merupakan tipe liat 1:1 seperti mineral liat kaolinit yang mepunyai kapasitas mengembang dan mengerut yang rendah. kaolinit yang memiliki daya serap terhadap air rendah sehingga tidak terjadi akumulasi air dalam tanah, hal ini sesuai pendapat Hardiyatmo (2006) bahwa, kestabilan lereng yang tekstur tanahnya halus sangat dipengaruhi oleh banyaknya air yang meresap ke dalam tanah yang dapat menambah berat tanah.

Faktor lain yang juga menyebabkan TL8 dan TL9 mengalami longsor adalah karena kedua titik ini berada pada daerah dekat permukiman tempat manusia beraktivitas, dibanding dengan TPB4 yang berada jauh dari permukiman. Hal ini sesuai dengan pendapat Massinai et al (2010) bahwa kegiatan manusia dalam mengolah lahan dan bermukim dapat merubah bentang alam dan mempercepat perubahan kondisi geologis yang pada akhirnya akan mempercepat terjadinya gerakan tanah. 


\section{KESIMPULAN}

Dari hasil identifikasi karakteristik ukuran butir dan mineral liat pada kejadian longsor dapat disimpulkan bahwa ukuran butiran didominasi oleh ukuran $0,5 \mathrm{~mm}$ dengan gradasi butiran yang seragam sehingga dapat membentuk pori mikro yang dapat terisi oleh air dan udara yang dapat mengakibatkan terjadinya akumulasi air jika intensitas hujan tinggi dan dapat memicu longsor sedangkan bentuk butiran yang tidak seragam dapat memperkecil terbentuknya pori mikro Mineral liat tipe 1:1 (kaolinit, nacrit, haloisit, dan dikit) memiliki daya serap air yang rendah dibanding mineral liat tipe 2:1 (montmorilonit, illit, vermikulit) karena adanya ruang antar misel yang dapat diisi oleh $\mathrm{H}_{2} \mathrm{O}$ (air) yang apabila terjadi intensitas hujan yang tinggi memnyebabkan akumulasi air dan apabila terdapat pada kelerengan yang curam dapat memincu terjadinya longsor.

\section{DAFTAR PUSTAKA}

Ahmad, A., Lopulisa, C., Imran, A. M., \& Baja, S. 2018. Soil physicochemical properties to evaluate soil degradation under different land use types in a high rainfall tropical region: A case study from South Sulawesi, Indonesia. In IOP Conference Series: Earth and Environmental Science (Vol. 157, No. 1, p. 012005). IOP Publishing.

Arif M. Dan Widodo A., 2008. Analisa Balik Kelongsoran (Studi Kasus Di Jember), Jurusan Teknik Sipil Ftsp- Its, Surabaya.

Arsyad, S. 2006. Konservasi Tanah \& Air.Cetakan Ketiga. Ipb Press, Bogor.

Cruden, D.M., 1991. A Simple Definition Of A Landslide. Bulletin International Association For Engineering Geology, 43: 27-29.
Hardiyatmo, Hary Christady. 2006 Penanganan Tanah Longsor Dan Erosi. Gadjah Mada University Press, Yogyakarta

Hanudin, E. 2004. Bahan Ajar Kimia Tanah. Jurusan Tanah Fakultas Pertanian UGM. Yogyakarta.

Husain, Ratna 2015. Tesis Geokimia Mineral Lempung Dan Implikasinya Terhadap Gerakan Tanah. Program Pascasarjana Universitas Hasanuddin, Makassar.

Holtz, R.D. And Kovacs, W.D., 1981, “An Introduction In Geotechnical Engineering. Prentice Hall Civil Engineering Ang Engineering Mechanic Series.

Karnawati, D. 2001. Bencana Alam Gerakan Tanah Indonesia Tahun 2000 (Evaluasi Dan Rekomendasi). Jurusan Teknik Geologi. Fakultas Teknik. Universitas Gadjah Mada. Yogyakarta.

Madjid. 2010. Sifat dan Ciri Tanah. Fakultas Pertanian Institut Pertanian Bogor: Bogor

Mitchell, James Kenneth. 1976. Fundamentals of Soil Behavior. Universitas Michigan

New Zealand Geotechnical Society Team. 2005. Field Description Of Soil And Rock, Guideline For The Field Classification And Description Of Soil And Rock For Enginee Ring Purposes. $\mathrm{Nz}$ Geotechnical Society Inc., New Zealand.

Panguriseng, Andi. Muh. Altin Massinai. Paharuddin. 2014. Analisis Sedimentasi Sungai Jeneberang Menggunakan Citra Spot-4 . FMIPA UNHAS, Makassar.

Solle, M. S., \& Ahmad, A. 2016. Landslides Intensity on River Morphology of 
Jeneberang Watershed after Collapse

of Caldera Wall at Mt.

Bawakaraeng. Research Journal of Applied Sciences, 11(9), 874-878.

Varnes, D.J., 1978. Slope Movement Types And Processes, In Schuster, R.L. Ang Krizek, R.J., Landslide Analysis And Control, Transportation Research Board, Special Report 176. National Academi Of Sciences Usa.

Utomo, Bayu Septiono Setyo. 2008. Identifikasi Daerah Rawan Longsor Di Kabupaten Bogor Jawa Barat.Ipb

Wesley, L.D., 2012. Mekanika Tanah. Badan Penerbit Pekerjaan Umum, Departemen Pekerjaan Umum, Jakarta.

Wibowo, Y Sunarya. 2011. Perilaku Sifat Fisik Dan Keteknikan Tanah Residual Batuan Volkanik Kuarter Di Daerah Cikijing, Majalengka, Jawa Barat. 